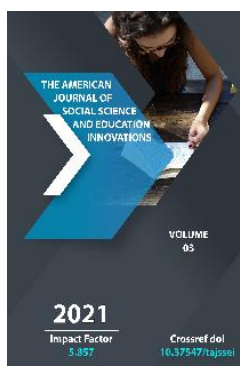

\title{
Creativity And Innovation Thinking
}

\author{
Gulnoza Sabirovna Sultanova \\ Associate Professor, PhD, Department Of Philosophy And National Idea Faculty Of Law, \\ Samarkand State University, Samarkand, Uzbekistan
}

Journal Website:

http://usajournalshub.c om/index,php/tajssei

Copyright: Original content from this work may be used under the terms of the creative commons attributes 4.0 licence.

\section{ABSTRACT}

In this article, a comparative analysis of creative and innovative thinking in a similar and different way will be made. The peculiarities of creativity and the essence of innovation are considered to be brought up as an object of philosophical research. Within the framework of the theme, it is mentioned about how our young people can use the opportunities created in our country on a large scale, about the achievement of the goals, the pursuit of innovation, creative thinking consisting of creative processes in a specific way and the various methods used in the mobilization of its implementation and their practical opportunities. Also, analytical analysis of the characteristic aspects of innovative thinking was carried out.The essence and essence of creative and innovational thinking, its distinctive features are considered to be brought up as an object of philosophical research. The views on innovation and creative thinking were also analyzed comparatively. In particular, it is noted that the formation of creative and innovative thinking is a period demand as well as a social need.

\section{KEYWORDS}

Creativity, innovation, contemplation, cognition, creativity, innovation, creative thinking, innovative thinking, innovative thinking, practice, development.

\section{INTRODUCTION}

As soon as our Republic gained independence, reforms and innovation updates were carried out in all spheres. In particular, radical changes in the economic, social and educational spheres were important for the introduction of 
innovations and for the improvement of creativity in people.

The current stage of social development opens up innovative changes in the economic sphere at a rapid pace, where innovation is becoming a common indicator of the growth of the viability of society and the ability of people to give space for creative activity, a sufficient assessment of its product and the acceptance of the results of these activities is the demand.

In addition to the framework of knowledge, skills and qualifications established in the state educational standards, the conditions for the preparation of highly qualified specialists with the ability to master the knowledge of fundamental and information technologies and carry out scientific research are considered.Public policy in the field of Personnel Training implies the formation of a comprehensively harmonious person-citizen through a system of continuous education, which is inextricably linked with the upbringing of a person from a mental and moral point of view.

We want to join the ranks of developed countries of the world, change our lives. To do this, it is important to develop innovative activity in the country and apply it to all spheres[1] so, if a person wants to be in harmony with the times, the only requirement is to have creative and innovative thinking. If creativity is associated with" imagination", innovation is associated with" implementation".

Today, especially innovative thinking and creative thinking are becoming popular. Therefore, "strategy of innovative development of the Republic of Uzbekistan in 2019-2021" was adopted in our country. According to the document, the strategy of innovative development of the Republic of Uzbekistan in 2019-2021 and the target indicators of innovative development of Uzbekistan until 2030 were approved. The development of human capital as the main factor determining the level of competitiveness of the country in the international arena and its innovative development has been defined as the main goal of the strategy. [2]

It should be noted that the economic growth of industry in the 21st century is ensured by the leading role of intellectualization of the main components of scientific and technical development and production in all spheres of the economy, including innovation policy. The search for rational directions of innovation policy and the promotion of technological changes are largely reflected in the level of Economic Development: countries that create favorable conditions for the achievement of innovation in global economic competition. It is not only aimed at developing a clear strategy, the formation of progressive technological structures, but also the ability to use the entire arsenal of tools and, first of all, the development of higher education in science and education, which is of great importance in the formation of an innovative policy to restore and increase the competitiveness of the industry. But creative thinking plays an important role in the implementation of innovative activities.

Innovation style of thinking is a form and system of social activity that focuses on shortening the time it takes for specialized enterprises and their renewal of new ideas, values and projects aimed at meeting the new needs and problems of man. 


\section{MATERIALS AND METHODS}

The term "innovative thinking" was used in the world philosophical Congress in 1993 it is believed that P.Delia entered. According to him, innovative thinking should be understood in its most general form as 'the development of thinking that leads to new results", the subject of which is "processes aimed at creating new fragments of reality, changing them or, conversely, maintaining a stable state of the existing reality".[3.232]

Innovative thinking is a rational compromise of these approaches: creative processes in it are used to form original ideas that connect imagination. These ideas are then classified, selected, organized and tested using rational and logical thinking.

Innovative thinking is a multi-stage davriy process, in which there are differences in the beginning, rise and completion, time intervals. The role and importance of innovative thinking in science and practice is largely dependent on the development of evristical methods and approaches.[4.52]

Russian scientists note that innovative thinking is of a constructive, transformational, practical and creative character. [5. 94-98] but these aspects are also present in creative thinking. This aspect shows their generality.

There are sub-factors (motivation, need) and object of innovative activity that lead to the assimilation of thinking and lifestyle of creative activity. Innovation processes represent the essence of change in social processes, are the source of development of society.[6.120]

Sh.S.Kushakov describes innovative thinking as follows: "innovative thinking is a creative thinking aimed at satisfying the growing and improving needs of a person, and at producing new ideas, projects and values on a regular basis in specialized communities and enterprises. Innovation is the development of innovation that takes place in society, the cause and effect of its transformation into a direction of broad social consciousness. [7.17]. As a result innovative thinking becomes social engine carrying out creative thinking.

\section{RESULTS}

Features of innovative thinking:

1) Originality-the ability to see things differently, doubt assumptions and get out of traditional approaches to work;

2) Commitment, perseverance, selfmotivation, enthusiasm and diligence;

3) Striving for perfection in everything and self-criticism;

4) Flexibility of mind and sense of humor;

5) Independence from other people's thoughts, resistance to external pressure and self-confidence;

6) Skepticism, curiosity, tolerance to uncertainty and complexity in problematic situations.

Creativity is the ability of a person to create new ideas, alternatives, solutions and opportunities in a unique and different way.

Creativeness is the ability to imagine something unpredictable, original and unique. It should be expressive, exciting and creative. This is a reflection of how well a person can think under any circumstances.So if creativeness is a spiritual cognitive process that takes place in more contemplation, then innovation is its application and result.Creativity is in theory, and innovation is its practice. 
Owners of unusual-minded creative thinking are tirelessly searching for the realization of their own destiny or with their own unique styles[8.13]. If creative thinking is a factor in the successful formation of new knowledge, innovative thinking is the key to their successful implementation, if the product of creativity is an idea, then the product of innovative thinking is a project on its basis to achieve a certain result under certain conditions.

There are several highlighted differences between creative and innovative thinking. The main difference between creativity and innovation is that the first refers to the concept of a new idea or plan, and the second refers to the beginning of something new that has not been introduced before. Creativity is the act of creating new ideas, fantasies and opportunities. Innovation is the introduction of something new and effective into society.

The introduction of new ideas into life is a novelty, the consequences of which must be positive. Innovation is carried out in an evolutionary and revolutionary way.

Innovation (lot, innovation - update, innovation) is:

1) Innovation, introduction of new things, modernization, reform;

2) In the economy-investment in new technology, new forms of organization and management of labor;

3) In linguistics-a new formation, a new phenomenon in the language;

4) In philosophy - that is, views, approaches, paradigms and conceptions;

5) In education - new teaching methods, tools.
Hence, innovative thinkingurni can be viewed as a separate type of thinking that "serves" the newsletter and ensures its success.

Another researcher, however, interprets innovation thinking as a nausea to creativity, "innovation thinking is a deviation (from the mold) from the deductive method in solving problematic situations."[9.58]

Therefore, innovative thinking is in all cases aimed at finding, discovering, creating something new in different areas of social practice, as well as updating previous ideas, views, evaluations, approaches and technologies.

According to many researchers, the ability to think creatively is to be able to see events, situations and objects in a new light and find an unusual solution to problems. Creative thinking, unlike template thinking, involves the rejection of the usual appearance of phenomena and objects, exposing the original solutions of tasks.

The peculiarity of innovative activity and the corresponding innovative thinking also implies a high level of cognitive abilities of the individual, which consists in the constant updating of theoretical knowledge, the ability to apply it in practical professional activity, the development of skills to use specific knowledge and experience in a particular field of professional activity.

Creative thinking represents a talent for creating new combinations, from the approach to solving a problem or from the thoughts that are there. This ability is often a nuisance to the personal abilities of the employee, but in this place it has a significant impact on the specific way of thinking and working skills. 
M.N.Abdullaeva believes that the process of creativity has a probable character. Because. it provides the possibility of more or less polyvariance with respect to some or even all components or properties of the process of forming the desired result. The creative process always comes out of the mold and, overcoming it, represents the transition to new tools and operations of scientific research activity.[10.12]

On the basis of the formation of nondirectional, sectorial innovation thinking is aimed at the development, implementation and dissemination of new ideas, after the activity becomes a routine process, creative thinking rises to the level of productive, creative activity, that is, productive activity. In this way, cognitive, intellectual innovation is formed. [11.571]

Creative thinking is a reflection of the industrial, Scientific and technical revolutions of the development of societies, formed during the period of sharp growth, progress and aimed at providing non-traditional thinking skills and development factors that contribute to the enrichment of new stages of technical development in modern society with human reserves. Creative thinking is also the reflection of modern managers, scientists, peadgogs, managers, creative thinking is required in the development of society from its lowest stages to its highest levels.This weapon of thoughthuman spirituality, nature, knowledge, mental potential-also includes the ability to use this very large base.

\section{CONCLUSION}

The main differences between creativity and innovation:
1. The quality of thinking about new ideas and turning them into reality is creativity. The act of practicing creative ideas is a novelty.

2. Creativeness is a creative process, unlike innovation, it is a productive process.

3. Creativeness can never be measured, but innovation can be measured.

4. Creativeness is the production of new and unique ideas. Rather, innovation is about bringing something better to the market.

5. Creativity and creativity does not require money, innovation makes money and fundraising.

6. There is no risk in creativity, the risk ' sa always associated with innovation.

Common between creativity and innovation:

1. Creativity is also reflected in innovation itself:

2. Both creativeness and innovation are the result of intelectual activity;

3. Creativity and innovation are also manifested in social development and lead to development;

4. Both creativity and innovation lead to qualitative and quantitative changes in all spheres of society.

5. Creativity also dictates one another as innovation is mutual dialectical involvement.

\section{REFERENCES}

1. http://uza.uz/ru/politics/prezidentarespubliki-uzbekistan-shavkatamirziyeev-25.01.2020

2. Decree of the president of the Republic of Uzbekistan "on approval of the strategy of innovative development of the Republic of Uzbekistan for 20192021" dated September 21, 2018 № PF- 
5544. National database of legislative data. Report this website 06185555441951 art.

3. Delia V.P. Innovative thinking in the XXI century. Moscow: De-Po, 2011. - P. 232.

4. Sultanova G.S. Postnoklassik style of scientific thought and innovation. Monographs. "Globoedit", 2019. - P. 163.

5. Usoltsev A.P., Shamalo T.N. the Concept of innovative thinking / / Pedagogical education in Russia. - 2014. - No. 1. - P. 94-98.

6. Tulenova K.J. Rasulev E.H. Education and innovation: a look into the future // Innovation in science and technology of Uzbekistan: problems, solutions and prospects. S., Samarkand, 2007. - P. 118-120.

7. Kushakov Sh.S. The concept of innovation thought // Problems of innovation thought in science and philosophy. Collection of scientific articles. - Samarkand: SamDU, 2010. P. 14-19.

8. Teresa M. Amabile. Creative thinking in business / TRANS. from English-M.: Alpina Business books. Harvard Business Review Classics Series), 2006. - P. 228.

9. Utemov V.V. Problems of open type as a tool for the development of innovative thinking // the Young scientist. - 2011. - No. 1. - P. 54-60.

10. Abdullaeva M.N. Innovative basis of scientific creativity/ / Innovation in science and technology: problems, solutions and prospects. Materials of the Republican scientific and practical conference. - Samarkand: SamDU, 2007. - P. 12-17.
11. Sultanova G.S. Innovative thinking and heuristics// ACADEMICIA: An International Multidisciplinary Research Journal https://www.saarj.com 1 ISSN: 22497137 Vol. 10, Issue 4, April 2020.-P. 568574 . 